\title{
Enumeration of Potential Teaching Methods in Higher Education: A Cross-Disciplinary Study
}

\author{
Khalid Mohiuddin (iD, ${ }^{1}$ Mohammad Aminul Islam, ${ }^{1}$ Mansoor Sharif, ${ }^{2}$ Shakila Nur, ${ }^{3}$ \\ Md. Shahrear Talukder, ${ }^{4}$ and Mohammed A Alghobiri ${ }^{1}$ \\ ${ }^{1}$ Department of Management Information Systems, King Khalid University, Abha 61471, Saudi Arabia \\ ${ }^{2}$ Department of Dentistry, King Khalid University, Abha 61471, Saudi Arabia \\ ${ }^{3}$ Department of English \& Modern Languages, North South University, Dhaka 1229, Bangladesh \\ ${ }^{4}$ Department of English, Bangladesh Army University of Science and Technology, Nilphamari 5300, Bangladesh
}

Correspondence should be addressed to Khalid Mohiuddin; drkhalidmk70@gmail.com

Received 4 March 2020; Revised 1 September 2020; Accepted 23 September 2020; Published 14 October 2020

Academic Editor: Haoran Xie

Copyright (C) 2020 Khalid Mohiuddin et al. This is an open access article distributed under the Creative Commons Attribution License, which permits unrestricted use, distribution, and reproduction in any medium, provided the original work is properly cited.

\begin{abstract}
In today's multifaceted academic context, selecting, adopting, and adapting appropriate teaching methods (TMs) have been a pivotal concern for teachers. No study, to the researchers' knowledge, has been conducted on compiling the maximum number of TMs in higher education. This study aims to list, describe, and provide a platform of the potential and the most practicing TMs in four major educational disciplines. This article, taking a cross-disciplinary lens, conducts an in-depth review of 90 articles and enumerates 110 TMs of higher education. It also identifies several TMs that are commonly used in each discipline. The article concludes that knowledge generated from this study fills up the existing literature gap. It calls attention to the current TM practices and provides teachers with an outline to employ available TMs in their respective disciplines.
\end{abstract}

\section{Introduction}

Higher education institutions exhibit quality education, prepare students for professional attainment and growth, and serve various stakeholders with diverse expectations [1]. Methods and approaches followed by teachers in their respective contexts work as a prominent catalyst. Again, selecting the right method and customizing it according to the need of students partially depend on teachers' knowledge of "definitions" and "types" of methods. Hence, a multifaceted academic context cataloging TMs and approaches suitable for higher education is essential for the academicians who are directly involved in teaching.

It is believed teachers should demonstrate an intention to adapt and customize methods aiming to improve students' learning [2]. Using methods for a positive change prompted by creativity, originality, and professionalism demands a good knowledge of the existing methods being used in teaching phenomenon. With a sound knowledge of
TMs, a teacher can improve and improvise the techniques to make the teaching-learning situation more conducive to students. A teacher can also be eclectic in using techniques if he has a commendable knowledge of the methods at hand. In every educational discipline, methods are, therefore, relatable to observable results for teaching and learning. Here, in this study, a few methods from four major disciplines have been discussed briefly to show how methods can bring substantial developments in the way teachers teach to facilitate students' learning. The grouping of disciplines, in this regard, has been flexible according to the nature of their academic content and knowledge [1].

The present academic milieu is getting more and more multidisciplinary and multicultural. This ever-changing situation poses extra challenges on the teachers and demands from them customization and modification of objectives, context, the contents of the lessons, and teacherstudent, student-teacher, and student-student communication patterns. Teachers' unfamiliarity with the TMs 
sometimes complicates the teaching-learning affair in the manifold. Henceforth, along with familiar types of TMs [3] used in the academic arena for a long time, some additional names, though not widely practiced by the academicians [4], have been listed in this article. On occasions, these fewer known methods could be useful for innovative teaching techniques.

Each discipline has its own requirements according to the objectives that it has to be achieved [5]. The course curriculum makes it possible to implement those objectives. There are several mechanisms of a curriculum, e.g., the contents, methods, and the process of the teaching. The curriculum or syllabus itself is settled following its educational objectives in respect of the participants, circumstances, and education programs. In teaching, a method is essential to conceptualize the whole teaching and learning binary to facilitate both teachers' teaching and students' learning. TMs are essential aspects of teaching and learning that define the undertakings of teachers and students, the quality of the teaching process [3] that tacitly sends a message about teaching techniques, students' progress in learning, and knowledge acquisition [6]. According to contemporary development in the teachinglearning milieu, the plurality of TMs and the need for more balanced use of them is an integral part of the development for each discipline. Insight into the understanding of TMs substantially impacts the quality of teaching. Understanding and analyzing TMs can lead to a deeper understanding of the quality of students' learning and the work of teachers [7].

When TMs are self-initiated, self-motivated, and selfvalued, they become meaningful and sustainable in a learning framework [8]. The application of TMs, techniques, or principles largely depends on multiple variables of the surrounding contexts. Teachers should adopt a method that is relevant, significant, and appropriate for their own classroom setup [9]. However, teachers always attempt to innovate in their teaching in order to improve student learning. Many forms of pedagogical innovation have been made in recent years to meet the challenging contexts of higher education $[2,10]$. We could hardly find a list of potential methods in one place. Besides, different educational disciplines use different methods to cater to the need of the students of their respective disciplines. Here, the concern is to present the potential methods through this study and provide a platform where the readers find many methods in one place.

1.1. Aim of the Study. This study aims to facilitate educators with the potential and the most practiced pedagogical methods in four educational disciplines, i.e., Arts and Humanities (AH), Medical Education (ME), Science and Engineering (SE), and Social Science (SS). It presents a manually conducted analysis of scientific literature on the available TMs to recognize the major four disciplines in higher education. It determines the TMs that are exclusively practiced in those disciplines and raises the potential research questions around TMs. It also provides educators with the choice of teaching methods for subjects to be taught.

Therefore, the study's approach is intended to examine the following two potential research questions:
RQ1: What are the potential TMs being practiced in higher education?

RQ2: What are the TMs exclusively being practiced in the four major disciplines?

\section{Methodology}

2.1. Data Acquiring, Retrieval, and Preanalysis. In information retrieval and manual analysis, deciding one procedure to search the keywords was challenging. Initially, the authors discussed several ways and keywords of the searches for information retrieval, e.g., scientific research databases, seminars and webinars, accessing library resources, and discussing with educators. Further, the choice of keywords, such as higher education, teaching methods, pedagogy, e-learning, traditional teaching methods, technology-based teaching methods, major disciplines, and sometimes the combination of such keywords were discussed arbitrarily. Additionally, some of these keywords narrate similar phenomena in the higher education context. The other challenges were how to choose disciplines and investigate the maximum number of TMs and the most practiced TMs in each discipline .

The study was conducted in three distinct phases:

(1) Phase 1: a systematic literature review for TMs in higher education institutions.

Firstly, the four disciplines-Science (Medical and Engineering), Social Science, and Arts and Humanities-were taken as major disciplines in higher education by considering the knowledge available at the platform of Web of Science (WoS) core collection. Besides, these disciplines are popular and widely taught in higher education institutions across the regions. Secondly, the literature was searched in a manner that would identify the maximum number of TMs across the disciplines. The presented study used the keywords robustly in the searches to maximize the review scope. Most importantly, the search results of hundreds of articles included at least one of these keywords, in either titles or abstracts. Besides, the articles were selected manually, screening the description of teaching methods and the disciplines where they were applied practically. In the end, the authors took opinions from several educators about the study's idea and intended to provide readers with the maximum number of potential TMs in a single article.

This review process was conducted for almost seven weeks accessing the different online scientific databases and other resources. During the search process, the keywords listed in the review design in Figure 1 were searched from the published articles. All the keywords were searched in different combinations to obtain the most similar and relevant articles from the databases. The databases were selected considering (i) education research journals, (ii) published quality articles, i.e., ISI indexed journals, (iii) other databases relevant to the study's aim. The criteria were the same for all the disciplines, i.e., teaching methods in 


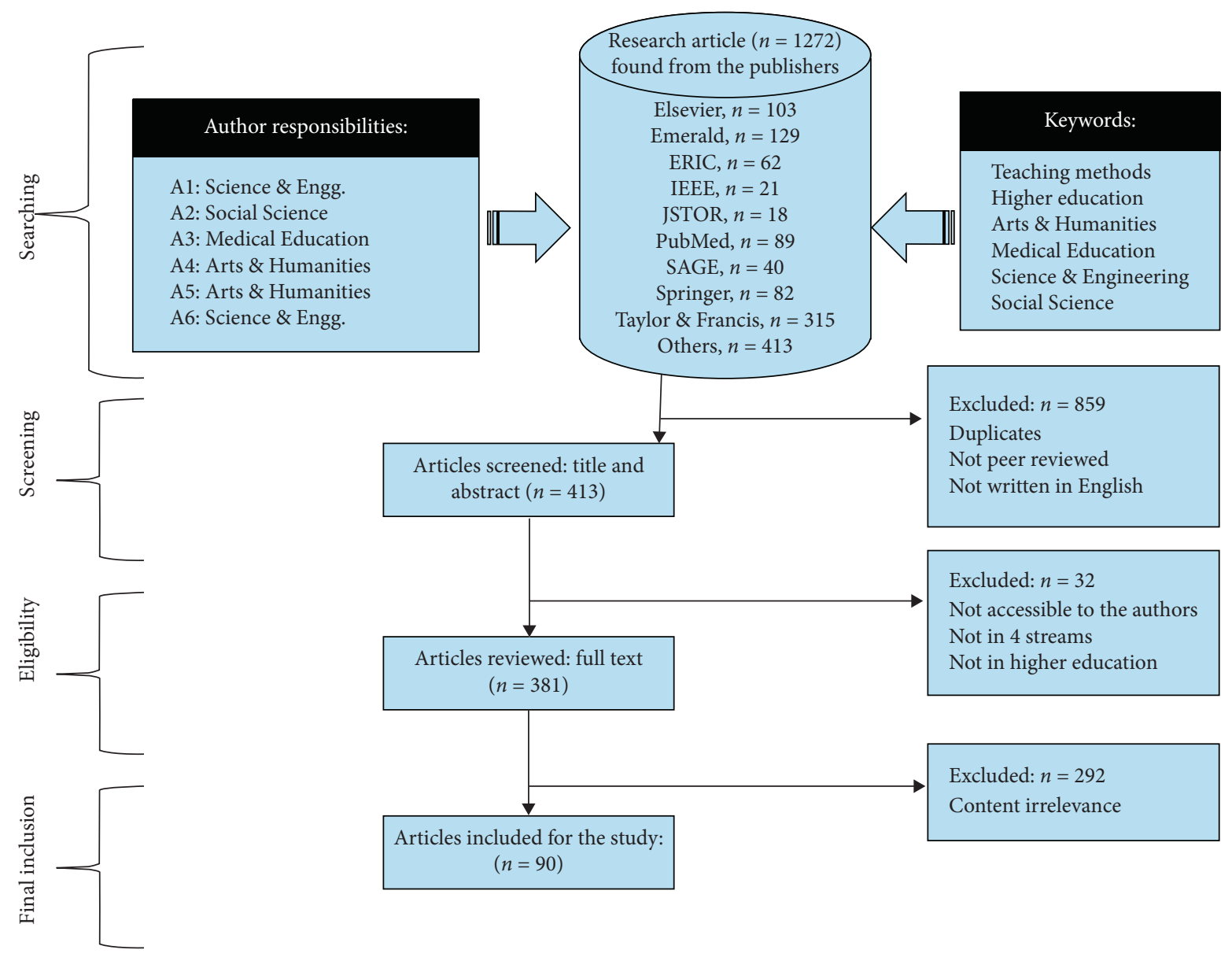

Figure 1: Review design.

higher education. Moreover, we considered some other research databases based on the content relevant to the study's idea.

ptFor the selection of articles, screening, eligibility, and final inclusion have been considered. Articles have been screened considering the titles and abstracts that included the keywords listed in Figure 1. For eligibility, the articles were included considering their accessibility to the authors and their suitability in the four disciplines of higher education. The articles were also carefully weighed for method, discussion, and result in line with the study's aim. Finally, these articles have been selected based on their complete content and cited in the body text and included in the reference section.

(2) Phase 2: an analysis of the literature review to find out the TMs in four educational disciplines.

Under phase 2, the selected articles were analyzed to find the TMs in four educational disciplines. Figure 2 describes the total number of articles that have been differentiated according to four disciplines. Analysis of these articles enumerated different TMs and led the study to phase 3 .

(3) Phase 3: identifying the exclusive TMs in four disciplines.
This phase analyzed the corpus of articles to determine the most practicing methods in each discipline exclusively. A thorough reading of the corpus of included articles led to consensus meetings which resulted in critical evaluation. Subsequently, different TMs which were found exclusively used in each discipline have been enlisted.

2.2. Referencing Timeline. This study mostly considers articles with TMs published in the last three decades. A few of the articles were dated very old and presented some of the TMs that had been significantly practiced for years. With the advent of modern methods, they might look obsolete, but those methods ushered the path to the latest. Authors found these references, though old, very relevant for discussion purposes. Besides, some methods discussed in those references are still useful in the teaching-learning context. In combination with the latest methods, old methods can be used partially to facilitate the learners. Subject and discipline-wise, some old methods occasionally prove useful, such as the grammar-translation method in Humanities and lecture method in all disciplines. Our referencing aims at showing the gradual progression in the teaching methods happening for decades in academia. 

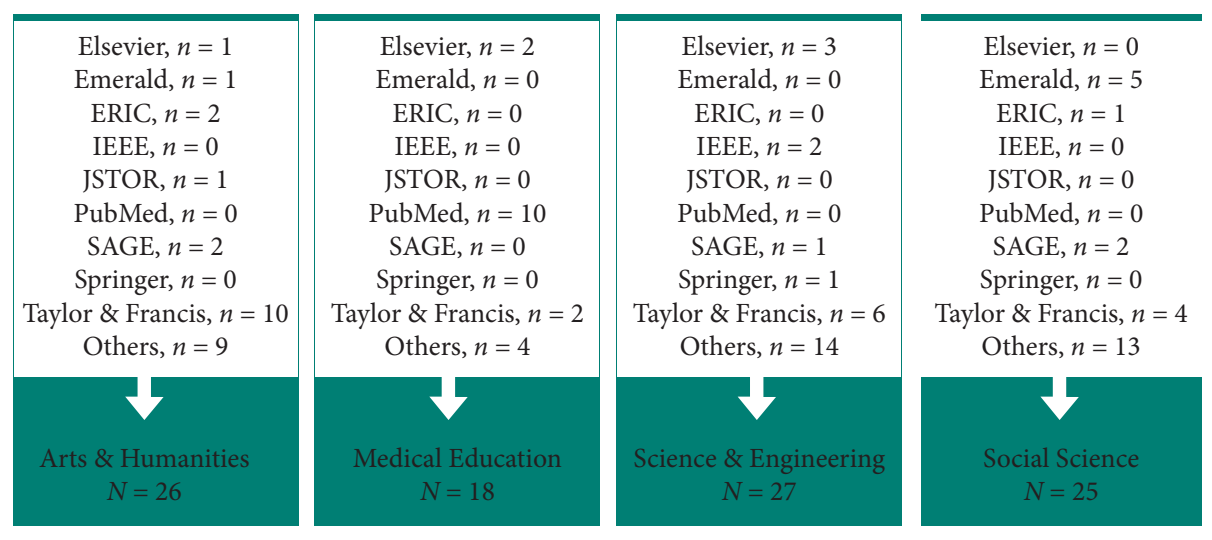

FIgURE 2: Number of articles studied for each discipline.

2.3. Methodology Selection. Howe and Abedin [11] searched 21 terms to carry out the review on a single TM, "classroomdialogue." Song et al. [12] used the same terms for their research. Further, they employed the Delphi method, consulted four experts to give their opinions about the terms used in the study, and employed bibliometric analysis to evaluate academic outputs of a specific research field and publication source for a period of time. The bibliometric analysis shows a research trend and its importance for a specific research field, e.g., education. It utilizes the impact factor of journals, citation count, and the h-index of authors to measure the influence of the research [12-14]. Similarly, topic modeling is a natural language processing method that mines research texts to discover semantic structures among them, which is used in social sciences [13]. On the contrary, this study used online and manual search using predefined keywords for article mining. Several potential research databases were needed to search rather than a single source because of its focus on multiple disciplines and an open range of time. The search was distributed among the authors according to their specialty. Factually, the bibliometric analysis was found difficult to be employed and inappropriate under such a case.

\section{Findings}

3.1. Teaching Methods in Higher Education. This article provides an in-depth search for the available TMs being practiced in the aforementioned disciplines in higher education. Additionally, it identifies that there is no such study that fully acknowledges similar kinds of work in listing TMs that teachers should adopt. It organizes the potential TMs in higher education, found in the literature review, and includes them in Table 1 to illustrate the study's findings. Remarkably, we found 110 TMs after careful review of 90 articles from the different publishers' databases.

3.2. TMs Exclusively Being Practiced in Each Discipline. One hundred and ten TMs share a lot of commonalities. However, Table 2 enlists 14 TMs in AH, 21 in ME, 22 in SE, and 25 in SS that are exclusively practiced in higher education. Exclusive TMs are the methods used for a particular discipline. Figure 3 illustrates 110 TMs of higher education that accommodates the number of exclusive TMs in each discipline and 28 TMs that are used across the disciplines.

3.2.1. Arts and Humanities. We found 14 exclusive TMs from 26 research materials that are generally being practiced in Arts and Humanities. According to our study, most of the methods found are active and student-centric, while a few are passive and teacher-centric. One study [9] found that in Asian context, CLT was unsuccessful at the classroom setup. The researchers suggested the teachers to consider educational, cultural, economic, and social factors in accepting any particular TM. Likewise, the grammar-translation method is limited to literature and fine arts [42]. Besides, students engage themselves in student-to-student mentoring and in real-world situations in different ways through artists' talks, consultancy, event-based learning, live projects, and simulating conditions of industry [5]. An analysis of the datadriven learning method shows that most of the students found the method interesting, productive, and motivating [40].

Similarly, under desuggestopedia, the classroom was found bright, cheerful, and positive, whereas, on the other hand, the discovery method intensifies students' knowledge, but no classroom was observed under this method [24]. As student diversity is increasing, methods based on multiple intelligence play a vital role in the pedagogy of higher education. The researcher suggested enhanced students' learning using this method [80]. Two student-centric methods task-teach-task and total physical response are used for learning foreign languages, and still, there are scopes to improve [91, 95].

3.2.2. Medical Education. We reviewed 17 articles with utmost care to find out the potential methods. In this case, we found 21 TMs which are exclusively being practiced over the years. As ME has been advanced in recent years, tapeslide program [72], CAL and tape/slide, didactic teaching, and models poorly fit the learning objectives. In contrast, three other practical methods: dissection, living and radiological, and prosection, have higher "fitness for purpose" and widely preferred by the anatomy students [31]. A recent 
TABLE 1: TMs in higher education.

\begin{tabular}{|c|c|c|c|}
\hline $\begin{array}{l}\text { Sl. } \\
\text { no. }\end{array}$ & Teaching methods & Description & Reference \\
\hline 1 & Action learning & $\begin{array}{l}\text { It is a problem-based learning, and the problem must be } \\
\text { real. While working on the problems, no one is supposed } \\
\text { to know the answer. }\end{array}$ & {$[15]$} \\
\hline 2 & Activity & $\begin{array}{c}\text { It is a learning method by doing something and a student- } \\
\text { centered approach. Students participate in rigorously for } \\
\text { quality learning. }\end{array}$ & {$[16]$} \\
\hline 3 & Applied project & $\begin{array}{l}\text { This is a teacher-facilitated approach in which students } \\
\text { with coordinated efforts acquire knowledge and skills. It } \\
\text { helps in solving the real problems by following certain } \\
\text { standards. }\end{array}$ & {$[17]$} \\
\hline 4 & Artists' talks & $\begin{array}{c}\text { This is based on practitioner talks and provides insights } \\
\text { into the broader view of the practices. Here students } \\
\text { engage based on these talks. }\end{array}$ & {$[5]$} \\
\hline 5 & Behavioral simulations & $\begin{array}{c}\text { This method primarily focuses on experiential } \\
\text { entrepreneurship activities where students learn business } \\
\text { behaviors and skills to develop certain entrepreneurial } \\
\text { aptitudes. }\end{array}$ & {$[4]$} \\
\hline 6 & Blog & $\begin{array}{l}\text { Here the instructor writes a summary after the lecture and } \\
\text { posts online on the course link. This summary includes } \\
\text { supplementary material and required action items to do } \\
\text { the homework or assignment. }\end{array}$ & {$[18]$} \\
\hline 7 & Both activity and lecture & It combines two methods-activity and lecture. & {$[16]$} \\
\hline 8 & Brainstorming & $\begin{array}{l}\text { It is a group activity where attempts are made to } \\
\text { determine a specific problem solution. It is defined as "an } \\
\text { organized way to allow the mind to produce ideas without } \\
\text { getting bogged down in trying to judge the value of those } \\
\text { ideas at the same time." }\end{array}$ & {$[19-22]$} \\
\hline 9 & Business plan creation & $\begin{array}{c}\text { It is an entrepreneurship teaching instrument for teachers } \\
\text { and entrepreneurial teacher for students. It consists of } \\
\text { several complex items that contribute to business } \\
\text { development. }\end{array}$ & [23] \\
\hline 10 & $\begin{array}{l}\text { Business/computer/game } \\
\text { simulations }\end{array}$ & $\begin{array}{l}\text { In the simulation method, learners experience artificial } \\
\text { representation based on real-life situations. Learners } \\
\text { asked to go through various situation-based instructions. } \\
\text { Learners generate a large number of results quickly in } \\
\text { ease of use environment. }\end{array}$ & {$[4,5,24-30]$} \\
\hline 11 & CAL and tape/slide & $\begin{array}{c}\text { Computer-assisted learning and tape/slide includes } \\
\text { computer-based instructional resources in teaching. With } \\
\text { the use of audiovisual aids, it focuses on interactive } \\
\text { instruction. }\end{array}$ & {$[31]$} \\
\hline 12 & $\begin{array}{l}\text { Case-based teaching } \\
\text { method }\end{array}$ & $\begin{array}{l}\text { Case-based teaching is an instructional technique and } \\
\text { tool, widely used in nursing, business, law, etc. Students } \\
\text { work on case studies and apply their knowledge to solve } \\
\text { real-world problems. The other teaching methods that } \\
\text { consist of the word "case" are almost the same. }\end{array}$ & {$[15,19,30,32-37]$} \\
\hline 13 & Clinical case & $\begin{array}{l}\text { This is an instruction-based method where cases are } \\
\text { selected carefully based on a teacher's guidance. This } \\
\text { enables students to apply their knowledge in clinical } \\
\text { medicine. }\end{array}$ & {$[27]$} \\
\hline 14 & $\begin{array}{c}\text { Communicative language } \\
\text { teaching }\end{array}$ & $\begin{array}{c}\text { This is a language teaching approach which involves } \\
\text { mostly speaking. It aims to make students communicative } \\
\text { competent, and teachers develop language skills learning } \\
\text { procedures. }\end{array}$ & [9] \\
\hline 15 & Consultancy & $\begin{array}{c}\text { In this method, students act as consultants to business } \\
\text { organizations. Here they engage in solving business issues } \\
\text { with the stakeholders. }\end{array}$ & {$[5]$} \\
\hline
\end{tabular}


TABle 1: Continued.

\begin{tabular}{|c|c|c|c|}
\hline $\begin{array}{l}\text { Sl. } \\
\text { no. }\end{array}$ & Teaching methods & Description & Reference \\
\hline 16 & $\begin{array}{l}\text { Cooperative learning } \\
\text { group }\end{array}$ & $\begin{array}{l}\text { This method is a learners' group of three or four students, } \\
\text { cooperating to learn the learning outcomes. They work on } \\
\text { some projects or assignments and submit the report to the } \\
\text { instructor. }\end{array}$ & {$[24,38,39]$} \\
\hline 17 & Data-driven learning & $\begin{array}{l}\text { This is learners-oriented data-driven method using } \\
\text { corpus data. The idea here is to make learners } \\
\text { autonomous researchers and discover facts about the } \\
\text { target language by using the language corpora. }\end{array}$ & {$[40]$} \\
\hline 18 & Demonstration & $\begin{array}{c}\text { It is described as a method of instruction, involves tutor, } \\
\text { learner, or both. Here a particular technique or skill } \\
\text { applies to a particular activity, and the learner mimics } \\
\text { that activity correctly. }\end{array}$ & {$[24,41]$} \\
\hline 19 & Desuggestopedia & $\begin{array}{l}\text { This method applies mostly to language teaching and } \\
\text { suggestions to pedagogy. It helps to eliminate students' } \\
\text { negative feelings and overcome the learning barriers. }\end{array}$ & {$[42]$} \\
\hline 20 & $\begin{array}{l}\text { Development of new } \\
\text { venture creation project }\end{array}$ & $\begin{array}{l}\text { This is an entrepreneurship teaching method that } \\
\text { generally applies to university entrepreneurship } \\
\text { programs. It helps professionals and students that are } \\
\text { committed to their venture creation projects. }\end{array}$ & {$[26,32]$} \\
\hline 21 & Dialogic & $\begin{array}{l}\text { Dialogic teaching engages students in dialogue. Instructor } \\
\text { explains the lesson to the students involving ongoing talk } \\
\text { between him and students. }\end{array}$ & {$[43,44]$} \\
\hline 22 & Didactic teaching & $\begin{array}{l}\text { This method helps students to learn theoretical } \\
\text { knowledge specifically those who depend on teachers' } \\
\text { guidance for reading and writing. }\end{array}$ & {$[31]$} \\
\hline 23 & Discovery method & $\begin{array}{l}\text { This method is usually based on content, and learners ask } \\
\text { to discover certain principles based on specific situations. } \\
\text { Here teacher organizes prior knowledge that helps in } \\
\text { discovering new information. }\end{array}$ & {$[24]$} \\
\hline 24 & Discussion sessions & $\begin{array}{l}\text { This method involves students and instructors in the } \\
\text { target topic. Students prepare some material on the topic } \\
\text { and discuss it in the session. }\end{array}$ & {$[24,45,46]$} \\
\hline 25 & Discussion and debates & $\begin{array}{l}\text { It is based on the distributed material earlier to the debate. } \\
\text { Students in small groups discuss the target material and } \\
\text { then openly debate. }\end{array}$ & {$[30]$} \\
\hline 26 & Dissection by students & $\begin{array}{l}\text { This is generally professional anatomists' method to } \\
\text { achieve course objectives. Students prefer this practical } \\
\text { method for their learning. }\end{array}$ & {$[31]$} \\
\hline 27 & $\begin{array}{l}\text { E-learning/web-based } \\
\text { learning }\end{array}$ & $\begin{array}{c}\text { This is an electronic network-based teaching method, and } \\
\text { students learn using ICT. Most of the institutions have } \\
\text { their virtual learning environment setup or learning } \\
\text { management systems, e.g., blackboard. }\end{array}$ & {$[5,15,47,48]$} \\
\hline 28 & Event-based learning & $\begin{array}{l}\text { This is an off-site learning mode where students engage in } \\
\text { real-time projects. These projects usually come from } \\
\text { industries, schools, and galleries. }\end{array}$ & {$[5]$} \\
\hline 29 & Experiments & $\begin{array}{l}\text { It is basically learning and teaching in experimental } \\
\text { sciences which include biological sciences. }\end{array}$ & {$[27]$} \\
\hline 30 & Expert script & $\begin{array}{l}\text { It is a tool for enhancing entrepreneurial skills and an } \\
\text { instructional pedagogy that helps students in improving } \\
\text { entrepreneurial expertise by following information } \\
\text { theorists' recommendations regarding script acquisition. }\end{array}$ & {$[4]$} \\
\hline 31 & Extended analogy & $\begin{array}{c}\text { This can be an alternative method to lecture method. It is } \\
\text { a combination of analogy and exaggeration. Instructors } \\
\text { develop an extended analogy that helps students to } \\
\text { understand a difficult topic. }\end{array}$ & {$[49]$} \\
\hline 32 & Face-to-face & $\begin{array}{c}\text { In this method, a teacher defines learning content and } \\
\text { applies it to learning complex theoretical topics. The } \\
\text { teacher provides the learning contents in short } \\
\text { presentations. }\end{array}$ & {$[50]$} \\
\hline
\end{tabular}


TABle 1: Continued.

\begin{tabular}{|c|c|c|c|}
\hline $\begin{array}{l}\text { Sl. } \\
\text { no. }\end{array}$ & Teaching methods & Description & Reference \\
\hline 33 & Flipped classroom & $\begin{array}{l}\text { It is the reverse of the traditional classroom where } \\
\text { students prepare their lessons at home. Students go } \\
\text { through lecture videos, text, online materials, and } \\
\text { PowerPoint presentations prepared by the instructor } \\
\text { before their class and practice them in the classroom. }\end{array}$ & {$[51-61]$} \\
\hline 34 & Game-based learning & $\begin{array}{l}\text { In this pedagogical approach, students get engaged and } \\
\text { involved in the use of the educational games. Game-based } \\
\text { activities improve students' learning and attitudes. }\end{array}$ & {$[30,62,63]$} \\
\hline 35 & $\begin{array}{c}\text { Grammar-translation } \\
\text { method }\end{array}$ & $\begin{array}{c}\text { Using this method, students learn grammar-translation } \\
\text { rules of a target/foreign language and apply them by } \\
\text { translating passages from their native language into the } \\
\text { target language and vice versa. }\end{array}$ & {$[42]$} \\
\hline 36 & Group discussion & $\begin{array}{l}\text { It is a modified form of classroom lecture method. Here a } \\
\text { teacher presents information and involves the students in } \\
\text { answering questions, opinions, and examples. }\end{array}$ & {$[5,15,19]$} \\
\hline 37 & Group oral presentation & $\begin{array}{l}\text { This method involves groups of three or four students. } \\
\text { Each group prepares a presentation on a given topic. The } \\
\text { student' group mutually decides the topic's segment and } \\
\text { presents it in the class. }\end{array}$ & {$[17,30]$} \\
\hline 38 & Group work & $\begin{array}{l}\text { It is a group-based method usually practiced in SE. This } \\
\text { helps in enhancing students' personal and learning skills. } \\
\text { Here activities involve such as sharing ideas, concerns, } \\
\text { mutual interest, and issues. }\end{array}$ & {$[5]$} \\
\hline 39 & Guest lecturer/speaker & $\begin{array}{c}\text { This is quite a motivating method for students. Here a } \\
\text { guest speaker delivers lectures, and students have the } \\
\text { opportunity to raise their doubts, issues, and share their } \\
\text { learning experience. }\end{array}$ & {$[15,17,64]$} \\
\hline 40 & Handout & $\begin{array}{l}\text { Here the instructor provides printed materials for several } \\
\text { things: problem-solving case studies, outlining a course of } \\
\text { action, placing a point of view, laboratory guidelines for } \\
\text { an experiment, and more. }\end{array}$ & {$[30,65]$} \\
\hline 41 & Homework & $\begin{array}{l}\text { This is the most popular method that applies to almost } \\
\text { every academic course. It includes a set of problems, a few } \\
\text { questions, and many other types based on the course and } \\
\text { the teacher's approach. }\end{array}$ & {$[18]$} \\
\hline 42 & Hybrid group & $\begin{array}{l}\text { This method is a blend of online education module that } \\
\text { delivers circular content and materials online, such as } \\
\text { videos. This method usually applies to ME. }\end{array}$ & {$[29]$} \\
\hline 43 & Hybrid tutorial & $\begin{array}{c}\text { The centerpiece of this method is a problem-based } \\
\text { learning tutorial system. Here students in small groups } \\
\text { learn the fundamentals of medicine through clinical } \\
\text { cases. }\end{array}$ & {$[66]$} \\
\hline 44 & In-class discussion & $\begin{array}{l}\text { It is primarily a class-based discussion method where } \\
\text { students in small groups discuss simulated scenes or real- } \\
\text { time scenarios. }\end{array}$ & {$[35]$} \\
\hline 45 & In-class exercises & $\begin{array}{l}\text { It involves active teacher-learner interaction. Here } \\
\text { students exercise lesson materials to gain proper } \\
\text { understanding with the help of the teacher. }\end{array}$ & {$[17]$} \\
\hline 46 & Individual presentation & $\begin{array}{l}\text { This is a learner-centric method where learners present } \\
\text { the target topic considering presentation dynamics. This } \\
\text { helps students improve their communication skills. }\end{array}$ & {$[15]$} \\
\hline 47 & Individual project & $\begin{array}{c}\text { It is a students' skills development method. Here an } \\
\text { individual student works on a project that helps the } \\
\text { student's learning strategies and dealing with complicated } \\
\text { situations. }\end{array}$ & {$[32]$} \\
\hline 48 & Individual written report & $\begin{array}{l}\text { The instructor assigns students to write an individual } \\
\text { report on class or review paper as homework. }\end{array}$ & {$[15,54]$} \\
\hline
\end{tabular}


TABle 1: Continued.

\begin{tabular}{|c|c|c|c|}
\hline $\begin{array}{l}\text { Sl. } \\
\text { no. }\end{array}$ & Teaching methods & Description & Reference \\
\hline 49 & Industrial training & $\begin{array}{l}\text { This method emphasizes entrepreneurial skills and equips } \\
\text { students with this skill. Students directly involve } \\
\text { entrepreneurial processes, such as industrial training. } \\
\text { IBL involves active inquiry where students make }\end{array}$ & {$[5,32]$} \\
\hline 50 & Inquiry-based learning & $\begin{array}{l}\text { questions and solve problems rather than processing } \\
\text { teacher-provided knowledge. }\end{array}$ & {$[5,67-69]$} \\
\hline 51 & Interview & $\begin{array}{l}\text { Students interview the boss or manager of a company } \\
\text { about the soft skills that are required to get a job. This } \\
\text { method gives the students a better understanding of real- } \\
\text { world business operations. }\end{array}$ & {$[64]$} \\
\hline 52 & Invited expert lecture & $\begin{array}{l}\text { An expert professor on a specific subject is invited to } \\
\text { conduct a lecture. }\end{array}$ & {$[54]$} \\
\hline 53 & Jigsaw & $\begin{array}{l}\text { It groups the students into teams. The overall task is cut } \\
\text { into pieces and distributed among the students of the } \\
\text { team. Each student is responsible for completing his task } \\
\text { outside of the class. The team then assembles the pieces to } \\
\text { complete the task. }\end{array}$ & {$[33,70]$} \\
\hline 54 & Journal article & $\begin{array}{l}\text { Students are instructed to read academic journal articles } \\
\text { on specific topics and later they discuss it in class. }\end{array}$ & {$[64]$} \\
\hline & & $\begin{array}{l}\text { This method was developed by Fred S. Keller and his } \\
\text { colleagues in the mid-1960s to help students to be self- } \\
\text { learners. It is a personalized learning method where }\end{array}$ & \\
\hline 55 & Keller method & $\begin{array}{c}\text { individual students independently move through their } \\
\text { course contents at their own pace. When a student passes } \\
\text { an individual unit of study, he can move onto the next } \\
\text { unit. }\end{array}$ & {$[71,72]$} \\
\hline 56 & Lab work & $\begin{array}{l}\text { Lab work helps students' learning by doing. What the } \\
\text { students learn in the classroom, they put it into practice. }\end{array}$ & {$[17,72]$} \\
\hline 57 & Lecture & $\begin{array}{l}\text { The lecture is the most widely used but criticized method } \\
\text { of instruction. This is a traditional passive method which } \\
\text { is useful for managing large classes. It instructs ideas, } \\
\text { facts, principles, and terminologies through verbal } \\
\text { presentation. }\end{array}$ & {$[5,15,18,19,24,30,33,35,41,45,71-77]$} \\
\hline 58 & $\begin{array}{l}\text { Lecture-discussion } \\
\text { combination }\end{array}$ & $\begin{array}{l}\text { Instructors use visual aids to deliver their materials. } \\
\text { Students make questions and discuss the topics } \\
\text { presented. This method forces students to contribute and } \\
\text { ask questions. }\end{array}$ & {$[17,33,39,45]$} \\
\hline 59 & Lecture handouts & $\begin{array}{l}\text { The instructor prepares and distributes hard copy of the } \\
\text { lecture notes before each lecture. The notes contain } \\
\text { exercises for the students. }\end{array}$ & {$[18]$} \\
\hline 60 & $\begin{array}{l}\text { Lecture with collaborative } \\
\text { exercises }\end{array}$ & $\begin{array}{l}\text { Traditional lectures are conducted, followed by } \\
\text { collaborative exercises. Topics are introduced in the } \\
\text { lectures and the exercises as well. }\end{array}$ & {$[78]$} \\
\hline 61 & Lecture with PowerPoint & $\begin{array}{l}\text { PowerPoint presentation with multimedia contents is } \\
\text { used during lecturing. }\end{array}$ & {$[16]$} \\
\hline 62 & Library exercise & $\begin{array}{c}\text { Library exercise expands students' knowledge. Students } \\
\text { are assigned tasks that have to be prepared from the } \\
\text { library materials. }\end{array}$ & {$[30]$} \\
\hline 63 & Life stories & $\begin{array}{c}\text { Students learn from real-life stories and write their own } \\
\text { biographies and plan the learning they needed for future } \\
\text { careers. }\end{array}$ & [4] \\
\hline 64 & Live projects & $\begin{array}{c}\text { Students experience projects in collaboration with } \\
\text { industry practitioners. }\end{array}$ & {$[5]$} \\
\hline 65 & Living and radiological & $\begin{array}{c}\text { Medical students learn from examining living subjects } \\
\text { and radiological images. }\end{array}$ & {$[31]$} \\
\hline 66 & Low-tech hands-on & $\begin{array}{c}\text { Instructors use limited technology in the classroom and } \\
\text { students pursue learning by doing. }\end{array}$ & {$[79]$} \\
\hline
\end{tabular}


TABle 1: Continued.

\begin{tabular}{|c|c|c|c|}
\hline $\begin{array}{l}\text { Sl. } \\
\text { no. }\end{array}$ & Teaching methods & Description & Reference \\
\hline 67 & $\begin{array}{l}\text { Making/reading peer } \\
\text { reviews }\end{array}$ & $\begin{array}{l}\text { The instructor gives projects to the students. Each report } \\
\text { of the projects is peer-reviewed by students in a double- } \\
\text { blind fashion following a rubric provided by the } \\
\text { instructor. }\end{array}$ & [18] \\
\hline 68 & Management simulation & $\begin{array}{l}\text { Under management simulation, students deal with the } \\
\text { real-world business organizations. They make a series of } \\
\text { decisions in business functional areas. They submit } \\
\text { strategy, management report, and instructor's approval } \\
\text { for simulated decision for course grading. }\end{array}$ & {$[36]$} \\
\hline 69 & Mind mapping & $\begin{array}{l}\text { Students use diagrams to visualize connections between } \\
\text { several ideas. They put ideas into paper or blackboard and } \\
\text { then use lines and curves to connect them. }\end{array}$ & {$[22]$} \\
\hline 70 & Models & Medical students use anatomical models in their learning. & {$[31]$} \\
\hline 71 & Multiple intelligence & $\begin{array}{l}\text { Howard Gardner developed this concept in the } 1980 \text { s } \\
\text { which asserts that people possess several types of } \\
\text { intelligence. Multiple intelligence theory can be applied in } \\
\text { teaching where the use of different bits of intelligence to } \\
\text { teach a concept allows students a chance to succeed in } \\
\text { learning. }\end{array}$ & {$[80]$} \\
\hline 72 & Online-only group & $\begin{array}{l}\text { Students receive all educational materials online that } \\
\text { include online interactive videos and recorded simulation } \\
\text { session. }\end{array}$ & [29] \\
\hline 73 & Peer learning & $\begin{array}{c}\text { Students interact with one another to learn a particular } \\
\text { subject area. This is a method of student-to-student } \\
\text { mentoring. }\end{array}$ & {$[5]$} \\
\hline 74 & Perceptional teaching & $\begin{array}{l}\text { Instructor gives an intuitive understanding of complex } \\
\text { topics which enables students to form conceptual } \\
\text { structures through perception of empirical meanings. }\end{array}$ & {$[50]$} \\
\hline 75 & Practical sessions & $\begin{array}{l}\text { Practical session makes links between theory and } \\
\text { practice. It includes clinical tests and laboratory work. } \\
\text { Students are divided into small groups and are engaged in }\end{array}$ & {$[5,46]$} \\
\hline 76 & Problem-solving & $\begin{array}{l}\text { a set of problems where they use their previous learning } \\
\text { and experience for a solution. }\end{array}$ & {$[17,24,26,30,72]$} \\
\hline 77 & Problem-based learning & $\begin{array}{l}\text { The problem drives the learning. Students in a small } \\
\text { group learn within the context of the issues that are } \\
\text { supervised by the instructors. }\end{array}$ & {$[5,27,46,50,75,81-89]$} \\
\hline 78 & $\begin{array}{l}\text { Project-based learning/ } \\
\text { group project }\end{array}$ & $\begin{array}{l}\text { PBL organizes learning around projects. It supports } \\
\text { students' learning by doing where they apply existing } \\
\text { knowledge and learn new things through project works. }\end{array}$ & {$[5,15,18,32,33,50,68]$} \\
\hline 79 & Prosection and demo & $\begin{array}{c}\text { Anatomy students get actual hands-on experience from } \\
\text { prosection and demo. }\end{array}$ & {$[31]$} \\
\hline 80 & Real-life case & $\begin{array}{c}\text { Students come across a real situation where they develop } \\
\text { real-time learning. }\end{array}$ & {$[26]$} \\
\hline 81 & $\begin{array}{l}\text { Research-oriented } \\
\text { teaching }\end{array}$ & $\begin{array}{c}\text { Students conduct research projects to identify new } \\
\text { findings. Research-oriented teaching develops students' } \\
\text { ability to make questions and find answers using scientific } \\
\text { research. }\end{array}$ & {$[5,16,50,90]$} \\
\hline 82 & Role model & $\begin{array}{l}\text { In business education, "real-life" entrepreneurs are } \\
\text { symbolized as role models who are more effective than } \\
\text { classroom instructors. They motivate students to explore } \\
\text { their true potentials and look for success. }\end{array}$ & {$[26]$} \\
\hline 83 & Role playing & $\begin{array}{l}\text { The instructor gives the students a scenario based on a } \\
\text { case. He defines the problem and students' roles clearly. } \\
\text { Students then are divided into several groups to present } \\
\text { their roles. Participants analyze the incidents with a } \\
\text { discussion. }\end{array}$ & {$[4,24-26,30]$} \\
\hline 84 & S-lecture & $\begin{array}{l}\text { S-lecture means student lecture. The course material is } \\
\text { divided among students to create their own lecture. } \\
\text { Students share their works among others. }\end{array}$ & {$[18]$} \\
\hline
\end{tabular}


TABle 1: Continued.

\begin{tabular}{|c|c|c|c|}
\hline $\begin{array}{l}\text { Sl. } \\
\text { no. }\end{array}$ & Teaching methods & Description & Reference \\
\hline 85 & Self-analysis & $\begin{array}{l}\text { It is helpful for student learning. Students conduct a self- } \\
\text { analysis assignment to analyze their own soft and } \\
\text { communication skills. With this analysis, students } \\
\text { understand their strengths and weaknesses. }\end{array}$ & {$[64]$} \\
\hline 86 & Self-study sessions & $\begin{array}{l}\text { Students practice self-study. They make their study } \\
\text { without having any direct supervision of the instructor. }\end{array}$ & {$[46]$} \\
\hline 87 & Seminar/workshop & $\begin{array}{l}\text { It is a group event where a student presents his academic } \\
\text { work followed by structured discussion. }\end{array}$ & {$[5,15,30]$} \\
\hline 88 & Serious games & $\begin{array}{c}\text { It is an interactive computer application through which } \\
\text { the users acquire knowledge and specific skills. It differs } \\
\text { from video games as its main objective is to provide } \\
\text { learning. }\end{array}$ & {$[28,74]$} \\
\hline 89 & $\begin{array}{l}\text { Simulated international } \\
\text { conference }\end{array}$ & $\begin{array}{l}\text { The conference is organized in the classroom. Students } \\
\text { gain scientific research skills from the simulated } \\
\text { conference. }\end{array}$ & {$[54]$} \\
\hline 90 & $\begin{array}{l}\text { Simulating conditions of } \\
\text { industry }\end{array}$ & Students have industry experience using this method. & {$[5]$} \\
\hline 91 & Small group & $\begin{array}{l}\text { This method involves small groups of students of two to } \\
\text { twenty participants. It includes tutorials, seminars, and } \\
\text { problem-solving }\end{array}$ & {$[5,30,35,75]$} \\
\hline 92 & Structured lectures & $\begin{array}{l}\text { In this method, the instructor focuses mainly on difficult } \\
\text { and inaccessible topics to the students. The instructor } \\
\text { uses slides, diagrams, and illustrations and covers most of } \\
\text { the syllabus. }\end{array}$ & {$[46]$} \\
\hline 93 & Tape-slide programs & $\begin{array}{l}\text { The instructor uses tape-slide programs that are the } \\
\text { audiovisual presentation in the classroom. }\end{array}$ & {$[72]$} \\
\hline 94 & Task-teach-task & $\begin{array}{l}\text { TTT is a student-centric teaching method where the } \\
\text { students complete their tasks without the instructor's } \\
\text { help. The instructor identifies the problems, suggests } \\
\text { solutions, and assigns other tasks. }\end{array}$ & [91] \\
\hline 95 & $\begin{array}{l}\text { Teaching through the } \\
\text { classics }\end{array}$ & $\begin{array}{l}\text { Instructors use classical literature, philosophy, and essays } \\
\text { to help students understanding entrepreneurship in } \\
\text { business education. }\end{array}$ & {$[4]$} \\
\hline 96 & $\begin{array}{l}\text { Teaching with real } \\
\text { patients }\end{array}$ & $\begin{array}{l}\text { Contact with real patients plays an important role in ME. } \\
\text { An experienced surgeon supervises the teaching with real } \\
\text { patients in a medical facility. Students observe the } \\
\text { patients and take notes. }\end{array}$ & {$[74]$} \\
\hline 97 & Team-based learning & $\begin{array}{c}\text { It is an active teaching method that increases students' } \\
\text { interaction and engagement. Here small group of } \\
\text { students work in the same team independently } \\
\text { throughout the semester. }\end{array}$ & [92-94] \\
\hline 98 & $\begin{array}{l}\text { Theoretical-practical } \\
\text { seminars }\end{array}$ & $\begin{array}{l}\text { Theoretical-practical seminars are conducted in medical } \\
\text { setups for better student understanding. }\end{array}$ & [27] \\
\hline 99 & Total physical response & $\begin{array}{l}\text { Dr. James J Asher developed this method which is based } \\
\text { on teaching and learning through physical action. In TPR, } \\
\text { instructors command the students in a foreign language, } \\
\text { and students respond with appropriate physical } \\
\text { movement. }\end{array}$ & [95-97] \\
\hline 100 & Tuition & $\begin{array}{l}\text { The instructor provides coaching to an individual student } \\
\text { or a small group of students. }\end{array}$ & {$[75]$} \\
\hline 101 & Use of animal models & $\begin{array}{c}\text { In ME, instructors use animal models for student } \\
\text { learning. }\end{array}$ & {$[74]$} \\
\hline 102 & $\begin{array}{l}\text { Video/video recorded } \\
\text { lecture }\end{array}$ & $\begin{array}{l}\text { The instructor displays a short video in the classroom on a } \\
\text { topic. Students participate in class discussion after } \\
\text { watching the video. }\end{array}$ & {$[4,15,16,30,35,64,65]$} \\
\hline 103 & Video + handout & $\begin{array}{l}\text { The instructor displays a short video in the classroom on a } \\
\text { topic. He also distributes hard copies of notes among the } \\
\text { students, and later, they participate in class discussions. }\end{array}$ & {$[65]$} \\
\hline
\end{tabular}


TABle 1: Continued.

\begin{tabular}{|c|c|c|c|}
\hline $\begin{array}{l}\text { Sl. } \\
\text { no. }\end{array}$ & Teaching methods & Description & Reference \\
\hline 104 & Video and microlecture & $\begin{array}{l}\text { The instructor displays videos in the classroom on a topic } \\
\text { followed by a microlecture. }\end{array}$ & {$[54]$} \\
\hline 105 & Virtual classroom & $\begin{array}{c}\text { A virtual classroom is conducted in an online platform } \\
\text { that allows live interaction between the instructor and the } \\
\text { students. }\end{array}$ & {$[26,98]$} \\
\hline 106 & Virtual internship & $\begin{array}{l}\text { Virtual internship simulates engineering problems and } \\
\text { practices in a web-based learning platform. }\end{array}$ & [99] \\
\hline 107 & $\begin{array}{l}\text { Virtual simulation } \\
\text { program }\end{array}$ & $\begin{array}{l}\text { Here students are involved in class activities that are not } \\
\text { possible in a physical classroom setup. }\end{array}$ & {$[100]$} \\
\hline 108 & Visual thinking strategies & $\begin{array}{l}\text { In this method, students visualize pieces of art in a } \\
\text { museum or classroom setting. The VTS instructor makes } \\
\text { questions and the students answer. Students also share } \\
\text { their thoughts about the piece of art. This method } \\
\text { improves students' critical thinking, visual literacy, and } \\
\text { communication skills. }\end{array}$ & {$[101]$} \\
\hline 109 & Web-based laboratories & $\begin{array}{l}\text { Increased class size, limited resources, and distance } \\
\text { learning force universities to use web-based laboratories. } \\
\text { The lab sessions use online video clips and simulations, } \\
\text { and labs are controlled over the Internet. }\end{array}$ & {$[5]$} \\
\hline 110 & Work-based learning & $\begin{array}{c}\text { Work-based learning addresses real working contexts. } \\
\text { Students study part-time and work on real-time } \\
\text { problems. }\end{array}$ & {$[5]$} \\
\hline
\end{tabular}

TABLE 2: TMs exclusively being practiced in each discipline.

\begin{tabular}{|c|c|c|c|}
\hline $\mathrm{AH}$ & ME & SE & SS \\
\hline Artists' talks & CAL and tape/slide & Activity & Applied projects \\
\hline Communicative & Clinical case & $\mathrm{B} \log$ & Behavioral simulation \\
\hline Language teaching & Didactic teaching & Both activity and lecture & Business plan creation \\
\hline Consultancy & Dissection by students & Dialogic & $\begin{array}{c}\text { Development of new venture creation } \\
\text { project }\end{array}$ \\
\hline Data-driven learning & Experiments & Extended analogy & Discussion and debates \\
\hline Desuggestopedia & Hybrid group & Face-to-face & Expert script \\
\hline Discovery method & Hybrid tutorial & Group work & Group presentation \\
\hline Event-based learning & Living and radiological & Homework & Guest speaker \\
\hline Grammar-translation method & Models & In-class discussion & In-class exercises \\
\hline Live projects & Online-only group & Invited expert lecture & Individual presentation \\
\hline Multiple intelligence & Prosection and demo & Jigsaw & Individual project \\
\hline Peer learning & Self-study sessions & Lecture handouts & Interview \\
\hline $\begin{array}{l}\text { Simulating conditions of } \\
\text { industry }\end{array}$ & Serious games & $\begin{array}{c}\text { Lecture with collaborative } \\
\text { exercises }\end{array}$ & Journal article \\
\hline Task-teach-task & Structured lectures & Lecture with PowerPoint & Lecture/discussion combination \\
\hline \multirow[t]{10}{*}{ Total physical response } & Tape-slide program & Low-tech hands-on & Library exercise \\
\hline & Teaching with real patients & Making/reading peer reviews & Life stories \\
\hline & $\begin{array}{c}\text { Theoretical-practical } \\
\text { seminars }\end{array}$ & Perceptional teaching & Management simulation \\
\hline & Tuition & S-lecture & Mind mapping \\
\hline & Use of animal models & $\begin{array}{l}\text { Simulated international } \\
\text { conference }\end{array}$ & Real-life case \\
\hline & Video + handout & Video and microlecture & Role model \\
\hline & VTS teaching method & Virtual internship & Self-analysis \\
\hline & & Web-based laboratories & Teaching through the classics \\
\hline & & & Virtual classroom \\
\hline & & & Virtual simulation program \\
\hline
\end{tabular}

study [29] in an educational setting suggested that students find more learner satisfaction in hybrid groups that combines online materials and short in-person simulation than online-only groups. Another study [66] found the hybrid tutorial to be successful because of increased student involvement and accountability. 


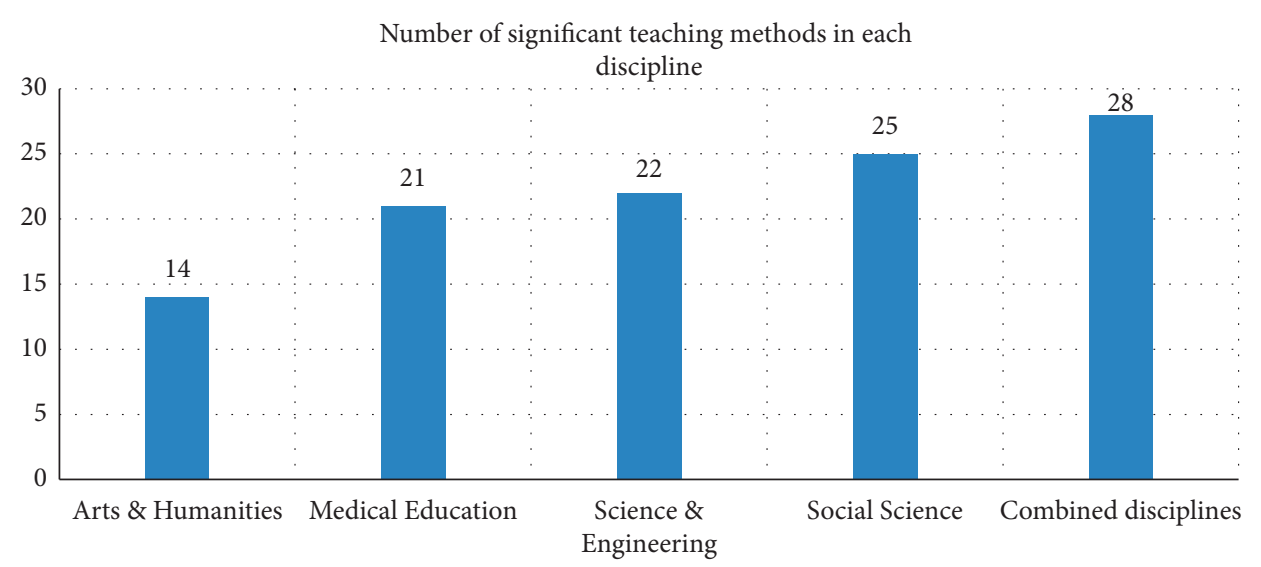

FIgUre 3: Number of significant TMs in each discipline.

It is evident that medical students require clinical tests and laboratory work. Therefore, students preferred structured lectures more than self-study [46]. Besides, using clinical cases, theoretical-practical seminars, and experiments, students participate more actively in their own learning process [27].

Moreover, teaching with real patients is limited by manpower shortage, and patients' safety, and similarly, the use of animal models is limited to a few medical facilities. Studies $[28,74]$ found that serious gaming could be ideal for overcoming these limitations. Working under a simulated environment prevents medical error, and thus, students acquire skills before practicing on real patients.

Tuition was used occasionally [75] and "video + handout" was significantly effective [65] for the medical students. Interestingly, one TM, VTS, from the humanities was used for training family medicine residents who found this method valuable in working together as a group [101].

3.2.3. Science and Engineering. For SE, we reviewed 27 articles, the maximum number of articles among all. We found 22 TMs used extensively while teaching the academic courses in this discipline. An interactive method like activity is useful for the classes that do not have a laboratory component. This was the most favorite method among other studied methods, and it encouraged the students to think. Although the lecture method is widely criticized [3], modification of this method like "lecture with collaborative exercises" was beneficial, and teachers can supervise a largesized class through group exercises [78]. In contrast, "both activity and lecture" and "lecture with PowerPoint" method were the least preferred by the students [16].

A recent study [18] in an engineering program compared the perceived effectiveness of different learning methods in one graduate and one undergraduate course. Graduate students were positive towards s-lecture, but they were undecided for making/reading peer reviews. On the other hand, undergraduate students found homework, lecture handouts, and s-lecture to be useful. Though the blog is an innovative method, students were undecided of its utility in their learning. They were also undecided for making/reading peer reviews.

Another method, extended analogy, helps students in understanding and retaining technical concepts. The researchers [49] suggested using extended analogy to hold students' attention in the learning process. Similarly, teachers can use dialogic technique [43, 44], in-class discussion [35], and group work [5] to involve students. Teachers can also use the traditional face-to-face method to deliver complex theoretical topics in the classroom and perceptional teaching to conceptualize empirical meanings [50]. Besides, a study [54] found invited expert lecture to be popular and more active than expected, and simulated international conference to be positive.

Carpenter [33] conducted pretest and posttest studies of the students using five different TMs. The researcher found that all five of the methods positively affected students' scores, and students improved the most using the jigsaw method. However, despite the improvement, students considered the jigsaw method to be the least valuable. On the other hand, Perkins and Saris [70] also found that students' perceptions of the jigsaw method were very positive.

In some situations, the low-tech hands-on technique can improve students' performance more than high-tech tools [79]. Nevertheless, analyzed data suggested that the hightech method, as the virtual internship, can develop students' design thinking and understanding in engineering [99], and today universities are using web-based laboratories to combat the increase in class sizes and the drain on resources [5].

3.2.4. Social Science. Social Science is one of the broader disciplines in higher education. In this discipline, we selected 25 articles for detailed analysis. We found 25 exclusively used TMs, the highest number of TMs in the four disciplines. In a study, Casado [17] investigated TMs preferred by the students. Surprisingly, most of the students preferred group presentation, and the combination of lecture and discussion more than applied projects, in-class exercises, and guest speakers as a TM. Similarly, Lonappan [15] conducted another research to compare the perception of different 
methods in teaching entrepreneurship education. In that study, only $12 \%$ and $5 \%$ of the students preferred individual presentation and action learning, respectively, which are less than other practice-based approaches. Besides, behavioral simulation, business plan creation, new venture creation projects, expert script, life stories, real-life case, role model, and individual project are widely used for teaching entrepreneurship [4, 23, 26, 32]. Carrier [4] also suggested that entrepreneurship can be taught using classical literature. Students can assimilate lessons from the characters of the novels and other essays. Another study [30] found that some methods might be enjoyable but not effective for a specific course. "Discussion and debate" and group presentation were rated high, but library exercise was rated low because of its limited connection to the course.

However, Anthony and Garner [64] found guest speakers to be very much influential. In contrast, Casado [17] found guest speaker as the least-liked method, and Lonappan [15] reported that only $15 \%$ of the students opted for the guest speaker. On the other hand, self-analysis and journal articles were found to be helpful. Surprisingly, students reported interviewing a boss or a manager to be least helpful [64]. Moreover, students perceived management simulation as a valuable instructional method for business courses [36], and mind mapping to be beneficial for learning business English [22]. Lastly, two tech-based methods, virtual classroom and virtual simulation program, are found to be interactive that increase student engagement in learning $[26,98,100]$.

3.2.5. Teaching Methods across the Disciplines. Among the 110 TMs, we found 28 methods to be used across the disciplines. These are the methods that were not being used exclusively for a specific discipline. They can be adapted to diverse circumstances. E-learning, lecture, and problembased learning were found to be in all four disciplines. Furthermore, 10 TMs were applied in three disciplines in different combinations. Table 3 lists the TMs that have been used across the disciplines.

\section{Discussion}

The question that incepted our study was, "How TMs are important in each discipline?" This led us to find out the TMs that were employed in different disciplines in higher education. Research for this was done, and we classified our findings into four major disciplines: $\mathrm{AH}, \mathrm{SE}, \mathrm{SS}$, and $\mathrm{ME}$. Numerous data gathered from different sources influenced us to narrow down our scope of research, and subsequently, we decided to pursue "What are the potential TMs being practiced in higher education?" and consequentially we investigated, "What are the TMs exclusively being practiced in four major disciplines?"

A self-contained study incorporating TMs across the four disciplines in higher education is hardly found in the academic arena. Individually cited articles focused on a small number of teaching methods used in each discipline, and hardly those articles discussed methods used across the
TABLE 3: TMs across the disciplines.

\begin{tabular}{|c|c|c|}
\hline $\begin{array}{l}\text { Sl. } \\
\text { no. }\end{array}$ & Teaching methods & $\begin{array}{l}\text { Educational } \\
\text { disciplines }\end{array}$ \\
\hline 1 & Brainstorming & $\mathrm{AH}, \mathrm{ME}, \mathrm{SS}$ \\
\hline 2 & $\begin{array}{c}\text { Business/computer/game } \\
\text { simulations }\end{array}$ & $\mathrm{AH}, \mathrm{ME}, \mathrm{SS}$ \\
\hline 3 & Case-based teaching method & SE, SS \\
\hline 4 & Cooperative learning group & $\mathrm{AH}, \mathrm{SS}$ \\
\hline 5 & Demonstration & $\mathrm{AH}, \mathrm{SE}$ \\
\hline 6 & Discussion sessions & $\mathrm{AH}, \mathrm{ME}, \mathrm{SS}$ \\
\hline 7 & E-learning/web-based learning & $\mathrm{AH}, \mathrm{ME}, \mathrm{SE}, \mathrm{SS}$ \\
\hline 8 & Flipped classroom & $\mathrm{AH}, \mathrm{ME}, \mathrm{SE}$ \\
\hline 9 & Game-based learning & SE, SS \\
\hline 10 & Group discussion & $\mathrm{AH}, \mathrm{SS}$ \\
\hline 11 & Handout & ME, SS \\
\hline 12 & Individual written report & SE, SS \\
\hline 13 & Industrial training & SE, SS \\
\hline 14 & Inquiry-based learning & $\mathrm{AH}, \mathrm{SE}, \mathrm{SS}$ \\
\hline 15 & Keller method & ME, SE \\
\hline 16 & Lab work & ME, SS \\
\hline 17 & Lecture & $\mathrm{AH}, \mathrm{ME}, \mathrm{SE}, \mathrm{SS}$ \\
\hline 18 & Practical sessions & ME, SE \\
\hline 19 & Problem-solving & $\mathrm{AH}, \mathrm{ME}, \mathrm{SS}$ \\
\hline 20 & Problem-based learning & $\mathrm{AH}, \mathrm{ME}, \mathrm{SE}, \mathrm{SS}$ \\
\hline 21 & $\begin{array}{l}\text { Project-based learning/group } \\
\text { project }\end{array}$ & $\mathrm{AH}, \mathrm{SE}, \mathrm{SS}$ \\
\hline 22 & Research-oriented teaching & SE, SS \\
\hline 23 & Role playing & $\mathrm{AH}, \mathrm{SS}$ \\
\hline 24 & Seminar/workshop & $\mathrm{AH}, \mathrm{SS}$ \\
\hline 25 & Small group & ME, SE, SS \\
\hline 26 & Team-based learning & $\mathrm{AH}, \mathrm{ME}, \mathrm{SS}$ \\
\hline 27 & Video/video recorded lecture & ME, SE, SS \\
\hline 28 & Work-based learning & $\mathrm{AH}, \mathrm{SE}$ \\
\hline
\end{tabular}

disciplines. Researchers have ignored the age-old methods, e.g.,lecture, Keller plan, and lecture with collaborative exercises, although they might have some potential in certain scenarios. The current study allows learning about potential TMs which are being practiced for decades in the academic arena. Moreover, it also enumerates new and contemporary methods that are evolving alongside emerging technologies, e.g., computer simulation, web-based learning, and virtual internship.

This study lists 110 TMs, which are explained briefly individually and narrowed down to identify exclusive TMs from each discipline. This process helps teachers understand the useful contributions of these methods in teaching and learning in their respective disciplines. If they need a more practical understanding of these methods, they can access the cited articles and get extensive understanding. Furthermore, comfortably they can get help from this article if they want to know about some identical and new methods.

While collecting data, we came across a number of articles in different disciplines; however, narrowing down our search, we studied a total of 90 research articles. Of the 90 articles, 84 articles focused on specific disciplines, whereas 6 articles discussed several disciplines and their associated TMs.

Of the 110 methods that we have enumerated from 90 articles, there has been varied distribution of these among 
different disciplines. Twenty-six (i.e., 27\%) of the articles were in reference to $\mathrm{AH}$, and 18 articles (19\%) were pertaining to ME; similarly, 27 articles (28\%) discussed SE, and 25 articles (26\%) were related to SS.

These findings resulted in 14 methods in AH, 21 methods for ME, 22 methods for SE, and 25 for SS that were exclusively used for each of the disciplines. The word "exclusively" used here is our way of saying that these methods did not overlap with the other disciplines. The findings also include 28 TMs across all four disciplines.

Surprisingly, only three methods were common with all four disciplines, i.e., lectures, e-learning, and problem-based learning. Lectures have been the age-old method of conveying the intent verbally. Even though it is a passive method of conveying information, it is effective when the number of participants is great and when the same information has to be conveyed to all at the same time. Problem-based learning is a relatively newer method of teaching which has become very popular due to its vocational approach. E-learning is another method which has been used by all disciplines in higher education due to the fact that it is effective in distance learning and convenient for study time suitability.

In reality, however, the TMs covered in this study would not be all the methods that exist in the four major disciplines. To the best of our efforts, we could find these methods after searching more than 1200 research materials.

\section{Limitations}

The study has identified a wide variety of TMs employed in four disciplines, as mentioned. Apart from focusing on practicing TMs in higher education, a few teaching approaches were also considered, as they have been used in all the four disciplines under study interchangeably. On the other hand, TMs that are employed in primary and secondary education were not included, as the study would be voluminous. The study's limitation also includes that only reputed journals, e.g., ISI, Scopus, and other peer-reviewed, were considered where some accepted methods might not have been reported.

\section{Conclusion}

This study has been conducted to methodically explore the most practicing TMs used in higher education. Attention was focused on four major disciplines that included $\mathrm{AH}, \mathrm{ME}$, SE, and SS. In our approach, we found that a broad spectrum of TMs has been practiced, and lecture is the most common method employed in the four disciplines. In the age of emerging technologies, electronic dependent modern TMs, like e-learning and computer-based simulations, are also employed massively across the disciplines.

The present study, though enlists TMs used in four disciplines, also admits its inefficiency in ensuring generalizability across every discipline in higher education. Future studies, in this regard, should include more disciplines to obtain a more holistic and comprehensive picture. Further studies employing questionnaires, interviews, and class observation data could be conducted to investigate essential factors influencing teachers' decisions to use TMs. Primary and secondary education levels could also be studied to this end. Moreover, there is much scope for future research in terms of the pedagogical dimensions that impact upon learners' classroom experiences. Relatedly, studies in this area could further focus on identifying pedagogical strategies that create, value, operate, and support a positive and inclusive classroom learning environment. Investigating the compatibility between TMs and assessment strategies used in the higher education level is another avenue for further research. The knowledge generated from this study, thus, potentially intends to bridge the literature lacuna, calls for attention to the current teaching practices, and provides critical insights for further research in higher education.

\section{Data Availability}

This article does not include any third-party data. It only includes the articles that have cited and listed in the reference section.

\section{Conflicts of Interest}

The authors declare that they have no conflicts of interest.

\section{Acknowledgments}

This work was supported by the Deanship of Scientific Research, King Khalid University, under Grant R.G.P-42-39.

\section{References}

[1] F. Nasser-Abu Alhija, "Teaching in higher education: good teaching through students' lens," Studies in Educational Evaluation, vol. 54, pp. 4-12, 2017.

[2] A. M. Walder, "Pedagogical Innovation in Canadian higher education: professors' perspectives on its effects on teaching and learning," Studies in Educational Evaluation, vol. 54, pp. 71-82, 2017.

[3] R. M. Felder, D. R. Woods, J. E. Stice, and A. Rugarcia, "The future of engineering education ii. teaching methods that work," Chemical Engineering Education, vol. 34, no. 1, pp. 26-39, 2000.

[4] C. Carrier, "Strategies for teaching entrepreneurship: what else beyond lectures, case studies and business plans?,"“Strategies for teaching entrepreneurship: what else beyond lectures, case studies and business plans?," in Handbook of Research in Entrepreneurship Education: A General Perspective, A. Fayolle, Ed., pp. 143-159, Edward Elgar Publishing, Cheltenham, United Kingdom, 2007.

[5] H. Fry, S. Ketteridge, and S. Marshall, A Handbook for Teaching and Learning in Higher Education, Enhancing Academic Practice: Routledge, New York, NY, USA, 3rd edition, 2009.

[6] E. Fischer and M. Hänze, "Back from "guide on the side" to "sage on the stage"? Effects of teacher-guided and studentactivating teaching methods on student learning in higher education," International Journal of Educational Research, vol. 95, pp. 26-35, 2019.

[7] C. M. Rubio, "Efective teachers-profesional and personal skills," Ensayos: Revista de la Facultad de Educación de Albacete, vol. 24, pp. 35-46, 2009. 
[8] L. Wei, "Unpacking tensions: an autobiographical narrative inquiry into the cross-cultural teaching journey of a TESOL teacher educator," "Unpacking tensions: an autobiographical narrative inquiry into the cross-cultural teaching journey of a TESOL teacher educator," in The Career Trajectories of English Language Teachers, P. Haworth and C. Craig, Eds., pp. 25-38, Symposium Books Ltd., Oxford, UK, 2016.

[9] L. Wei, H. Lin, and F. Litton, "Communicative language teaching (CLT) in EFL context in asia," Asian Cultural History, vol. 10, no. 2, 2018.

[10] A. Salamzadeh and D. A. Kirby, "New venture creation: how start-ups grow?” AD-minister, vol. 30, no. 30, pp. 9-29, 2017.

[11] C. Howe and M. Abedin, "Classroom dialogue: a systematic review across four decades of research," Cambridge Journal of Education, vol. 43, no. 3, pp. 325-356, 2013.

[12] Y. Song, X. Chen, T. Hao, Z. Liu, and Z. Lan, "Exploring two decades of research on classroom dialogue by using bibliometric analysis," Computers \& Education, vol. 137, pp. 12-31, 2019.

[13] X. Chen, D. Zou, G. Cheng, and H. Xie, "Detecting latent topics and trends in educational technologies over four decades using structural topic modeling: a retrospective of all volumes of computers \& education," Computer Education, vol. 151, Article ID 103855, 2020.

[14] X. Chen, D. Zou, and H. Xie, "Fifty years of British journal of educational technology: a topic modeling based bibliometric perspective," British Journal of Educational Technology, vol. 51, no. 3, pp. 692-708, 2020.

[15] D. J. Lonappan, "Pedagogical innovations in teaching entrepreneurship," International Journal of Scientific Research, vol. 2, no. 2, pp. 241-243, 2013.

[16] R. L. Rosier, "Students' perceptions of interactive biology instruction," The American Biology Teacher, vol. 79, no. 8, pp. 621-625, 2017.

[17] M. Casado, "Teaching methods in higher education: a student perspective," Journal of Hospitality \& Tourism Education, vol. 12, no. 2, pp. 65-70, 2000.

[18] A. J. Magana, C. Vieira, and M. Boutin, "Characterizing engineering learners' preferences for active and passive learning methods," IEEE Transactions on Education, vol. 61, no. 1, pp. 46-54, 2018.

[19] R. Bennett, "Business lecturers' perceptions of the nature of entrepreneurship," International Journal of Entrepreneurial Behavior \& Research, vol. 12, no. 3, pp. 165-188, 2006.

[20] Z. Ghabanchi and S. Behrooznia, "The impact of brainstorming on reading comprehension and critical thinking ability of EFL learners," Procedia-Social and Behavioral Sciences, vol. 98, pp. 513-521, 2014.

[21] B. Goswami, A. Jain, and B. Koner, "Evaluation of brainstorming session as a teaching-learning tool among postgraduate medical biochemistry students," International Journal of Applied and Basic Medical Research, vol. 7, no. 5, p. 15, 2017.

[22] M.-A. Sim and A.-M. Pop, "Mind mapping and brainstorming as methods of teaching business concepts in English as a foreign language," Academic Science Journal, Psychological Series, vol. 1, pp. 75-83, 2012.

[23] B. Honig, "Entrepreneurship education: toward a model of contingency-based business planning," Academy of Management Learning \& Education, vol. 3, no. 3, pp. 258-273, 2004.

[24] D. Adom, S. Adam, and O. Agyemang, "Effective instructional methods and strategies for teaching art history," International Journal of Art and Art History, vol. 4, no. 2, pp. 45-62, 2016.
[25] F. S. Ahmad, R. Baharun, and S. H. A. Rahman, "Interest in entrepreneurship: an exploratory study on engineering and technical students in entrepreneurship education and choosing entrepreneurship as a career," Faculty of Management and Human Resources Development University Teknologi Malaysia, 2004.

[26] A. Fayolle and B. Gailly, "From craft to science: teaching models and learning processes in entrepreneurship education," Journal of European Industrial Training, vol. 32, no. 7, pp. 569-593, 2008.

[27] B. Gal, M. Rubio, E. Iglesias, and P. González, "Evaluation of participatory teaching methods in undergraduate medical students' learning along the first academic courses," PLoS One, vol. 13, no. 1, 2018.

[28] M. Graafland, J. M. Schraagen, and M. P. Schijven, "Systematic review of serious games for medical education and surgical skills training," British Journal of Surgery, vol. 99, no. 10, pp. 1322-1330, 2012.

[29] M. R. Konia, M. Richtsfeld, A. D. Johnson, M. Lougee, C. Cohn, and S. Morgan, "An observational study of 3 different transfusion medicine teaching methods for medical students," Transfusion Medicine Reviews, vol. 32, no. 2, pp. 117-122, 2018.

[30] A. Sivan, R. W. Leung, C.-c. Woon, and D. Kember, "An implementation of active learning and its effect on the quality of student learning," Innovations in Education and Training International, vol. 37, no. 4, pp. 381-389, 2000.

[31] B. J. Moxham and S. A. Moxham, "The relationships between attitudes, course aims and teaching methods for the teaching of gross anatomy in the medical curriculum," European Journal of Anatomy, vol. 11, pp. 19-30, 2007.

[32] Z. Arasti, M. Kiani Falavarjani, and N. Imanipour, "A study of teaching methods in entrepreneurship education for graduate students," Higher Educational Studies, vol. 2, no. 1, 2012.

[33] J. M. Carpenter, "Effective teaching methods for large classes," Journal of Family and Consumer Sciences Education, vol. 24, no. 2, pp. 13-23, 2006.

[34] T. G. Gill, "The complexity and the case method," Management Decision, vol. 52, no. 9, pp. 1564-1590, 2014.

[35] Q. Liu, W. Zhao, D. Liu, and J. Ji, "Evaluation of situational case-based teaching technique in engineering education," ACM International Conference Proceeding Series August 2017, Leipzig, Germany.

[36] W. G. Miles, W. D. Biggs, and J. N. Schubert, "Student perceptions of skill acquisition through cases and a general management simulation," Simulation \& Games, vol. 17, no. 1, pp. 7-24, 1986.

[37] R. Moreno and B. Park, "Cognitive load theory: historical development and relation to other theories," in Cognitive Load Theory, pp. 7-28, Cambridge University Press, Cambridge, UK, 2010.

[38] D. W. Johnson and R. T. Johnson, "Relationships between black and white students in intergroup cooperation and competition," The Journal of Social Psychology, vol. 125, no. 4, pp. 421-428, 1985.

[39] R. L. Morgan, J. E. Whorton, and C. Gunsalus, "A comparison of short term and long term retention: lecture combined with discussion versus cooperative learning," International Journal of Psychology, vol. 27, no. 1, pp. 53-58, 2000.

[40] S. Götz and J. Mukherjee, "Evaluation of data-driven learning in university teaching: a project report," "Evaluation of data-driven learning in university teaching: a project 
report," in Corpus Technology and Language Pedagogy: New Resources, New Tools, New Methods, S. Braun, K. Kohn, and J. Mukherjee, Eds., pp. 49-67, Frankfurt am Main: Peter Lang, New York, NY, USA, 2006.

[41] K. Giridharan and R. Raju, "Impact of teaching strategies: demonstration and lecture strategies and impact of teacher effect on academic achievement in engineering education," International Journal of Educational Sciences, vol. 14, no. 3, pp. 174-186, 2016.

[42] D. Larsen-Freeman and M. Anderson, Techniques and Principles in Language Teaching, Oxford University Press, Oxford, UK, 3rd edition, 2011.

[43] A. Bakker, J. Smit, and R. Wegerif, "Scaffolding and dialogic teaching in mathematics education: introduction and review," ZDM, vol. 47, no. 7, pp. 1047-1065, 2015.

[44] S. Lehesvuori, J. Viiri, and H. Rasku-Puttonen, "Introducing dialogic teaching to science student teachers," Journal of Science Teacher Education, vol. 22, no. 8, pp. 705-727, 2011.

[45] D. L. Barnes and D. Blevins, "An anecdotal comparison of three teaching methods used in the presentation of microeconomics," Educational Research and Questions, vol. 27, no. 4, p. 41, 2004.

[46] M. Hamza, Inam-Ul-Haq, S. Hamid, M. Nadir, and N. Mehmood, "Effect of moderate learning style-teaching mode mismatch on academic performance among 2ndyear medical students in Pakistan," Indian Journal of Psychiatry, vol. 60, no. 1, pp. 109-113, 2018.

[47] P. Berman, "E-learning concepts and techniques," 2006.

[48] I. Masic, "E-learning as new method of medical education," Acta Informatica Medica, vol. 16, no. 2, p. 102, 2008.

[49] J. Matocha, T. Camp, and R. Hooper, "Extended analogy: an alternative lecture method," ACM SIGCSE Bulletin, vol. 30, no. 1, pp. 262-266, 1998.

[50] E. Mäkiö-Marusik, J. Mäkio, and J. Kowal, "Implementation of task-centric holistic agile approach on teaching cyber physical systems engineering," AMCIS 2017-America's Conference on Information Systems: A Tradition of Innovation August 2017, Boston, MA, USA.

[51] F. Chen, A. M. Lui, and S. M. Martinelli, "A systematic review of the effectiveness of flipped classrooms in medical education," Medical Education, vol. 51, no. 6, pp. 585-597, 2017.

[52] J. S. Chen Hsieh, W.-C. V. Wu, and M. W. Marek, "Using the flipped classroom to enhance EFL learning," Computer Assisted Language Learning, vol. 30, no. 1-2, pp. 1-21, 2017.

[53] D. Zou and H. Xie, "Flipping an English Writing Class with Technology-Enhanced Just-In-Time Teaching and Peer Instruction," Interactive Learning Environments, Routledge, Abingdon, UK, 2018.

[54] X. Fan, J. Zhou, and M. Tong, "Teaching methods of engineering practice course for senior undergraduate students,"Proceedings of 2015 IEEE International Conference on Teaching, Assessment and Learning for Engineering, TALE December 2015, Zhuhai, China.

[55] H.-T. Hung, "Flipping the classroom for English language learners to foster active learning," Computer Assisted Language Learning, vol. 28, no. 1, pp. 81-96, 2015.

[56] A. Karabulut-Ilgu, N. Jaramillo Cherrez, and C. T. Jahren, "A systematic review of research on the flipped learning method in engineering education," British Journal of Educational Technology, vol. 49, no. 3, pp. 398-411, 2018.

[57] C. Liu, S. Sands-Meyer, and J. Audran, "The effectiveness of the student response system (srs) in English grammar learning in a flipped English as a foreign language (EFL) class," Interactive Learning Environments, vol. 27, no. 8, pp. 1178-1191, 2019.

[58] J. Mehring, "Present research on the flipped classroom and potential tools for the EFL classroom," Computers in the Schools, vol. 33, no. 1, pp. 1-10, 2016.

[59] D. P. Sam, "Natural approach of teaching English language on a flipped classroom platform to tertiary level engineering learners," International Journal of Educational Sciences, vol. 14, no. 1-2, pp. 13-18, 2016.

[60] B. Santikarn and S. Wichadee, "Flipping the classroom for English language learners: a study of learning performance and perceptions," International Journal of Emerging Technologies in Learning (IJET), vol. 13, no. 9, pp. 123-135, 2018.

[61] R. L. Su Ping, E. Verezub, I. F. bt Adi Badiozaman, and W. S. Chen, "Tracing EFL students' flipped classroom journey in a writing class: lessons from Malaysia," Innovations in Education and Training International, vol. 57, no. 3, pp. 305-316, 2019.

[62] C. A. Bodnar, D. Anastasio, J. A. Enszer, and D. D. Burkey, "Engineers at play: games as teaching tools for undergraduate engineering students," Journal of Engineering Education, vol. 105, no. 1, pp. 147-200, 2016.

[63] L. F. Braghirolli, J. L. D. Ribeiro, A. D. Weise, and M. Pizzolato, "Benefits of educational games as an introductory activity in industrial engineering education," Computers in Human Behavior, vol. 58, pp. 315-324, 2016.

[64] S. Anthony and B. Garner, "Teaching soft skills to business students," Business and Professional Communication Quarterly, vol. 79, no. 3, pp. 360-370, 2016.

[65] F. Baessler, A. Ciprianidis, A. Z. Rizvi et al., "Delirium: medical students' knowledge and effectiveness of different teaching methods," The American Journal of Geriatric Psychiatry, vol. 27, no. 7, pp. 737-744, 2019.

[66] D. L. Cardozo, L. Raymond, and B. White, "A structured PBL tutorial involving small teams for teaching the human nervous system," Medical Teacher, vol. 34, no. 11, 2012.

[67] P. Blessinger and J. M. Carfora, Innovative Approaches in Teaching and Learning: An Introduction to Inquiry-Based Learning for the Arts, Humanities, and Social Sciences, Emerald Group Publishing, Bingley, UK, 2014.

[68] A. M. Connor, S. Karmokar, and C. Whittington, "From STEM to STEAM: strategies for enhancing engineering \& technology education," International Journal of Engineering Pedagogy (IJEP), vol. 5, no. 2, p. 37, 2015.

[69] F. C. Manista and M. P. Gillespie, "Using enquiry-based learning methods to teach finnegans wake to undergraduates," Arts and Humanities in Higher Education, vol. 10, no. 1, pp. 85-98, 2011.

[70] D. V. Perkins and R. N. Saris, "A "jigsaw classroom" technique for undergraduate statistics courses," Teaching of Psychology, vol. 28, no. 2, pp. 111-113, 2001.

[71] M. A. Philippas and R. W. Sommerfeldt, "Keller vs lecture method in general physics instruction," American Journal of Physics, vol. 40, no. 9, pp. 1300-1306, 1972.

[72] P. Schwartz, "Teaching methods down under," Biochemical Education, vol. 8, no. 1, pp. 16-20, 1980.

[73] R. W. Griffin and W. E. Cashin, "The lecture and discussion method for management education: pros and cons," Journal of Management Development, vol. 8, no. 2, pp. 25-32, 1989.

[74] P. Haubruck, "Evaluation of app-based serious gaming as a training method in teaching chest tube insertion to medical students: randomized controlled trial," Journal of Medicine Internet Research, vol. 20, no. 5, 2018. 
[75] U. Holm and K. Aspegren, "Pedagogical methods and affect tolerance in medical students," Medical Education, vol. 33, no. 1, pp. 14-18, 1999.

[76] A. Revell and E. Wainwright, "What makes lectures 'unmissable'? Insights into teaching excellence and active learning," Journal of Geography in Higher Education, vol. 33, no. 2, pp. 209-223, 2009.

[77] R. B. Spence, "Lecture and class discussion in teaching educational psychology," Journal of Educational Psychology, vol. 19, no. 7, pp. 454-462, 1928.

[78] P. de Caprariis, C. Barman, and Magee, "Monitoring the benefits of active learning exercises in introductory survey courses in science: an attempt to improve the education of prospective public school teachers," Journal of Scholarship, Teaching and Learning, vol. 1, no. 2, pp. 13-23, 2001.

[79] J. Geller and R. Dios, "A low-tech, hands-on approach to teaching sorting algorithms to working students," Computers \& Education, vol. 31, no. 1, pp. 89-103, 1998.

[80] E. Barrington, "Teaching to student diversity in higher education: how multiple intelligence theory can help," Teaching in Higher Education, vol. 9, no. 4, pp. 421-434, 2004.

[81] A. Klegeris and H. Hurren, "Impact of problem-based learning in a large classroom setting: student perception and problem-solving skills," Advances in Physiology Education, vol. 35, no. 4, pp. 408-415, 2011.

[82] S. Knudsen, "Students are doing it for themselves - 'the problem-oriented problem' in academic writing in the humanities," Studies in Higher Education, vol. 39, no. 10, pp. 1838-1859, 2014.

[83] S. Mierson, "A problem-based learning course in physiology for undergraduate and graduate basic science students," American Journal of Physiology, vol. 275, no. 6, p. 2, 1998.

[84] N. Othman and M. I. A. Shah, "Problem-based learning in the English language classroom," English Language Teaching, vol. 6, no. 3, pp. 125-134, 2013.

[85] P. Balve, V. Krüger, and L. Tolstrup Sørensen, "Applying the Kanban method in problem-based project work: a case study in a manufacturing engineering bachelor's programme at Aalborg University Copenhagen," European Journal of Engineering Education, vol. 42, no. 6, pp. 1512-1530, 2017.

[86] H. S. Barrows, "A taxonomy of problem-based learning methods," Medical Education, vol. 20, no. 6, pp. 481-486, 1986.

[87] B. Dahl, "What is the problem in problem-based learning in higher education mathematics," European Journal of Engineering Education, vol. 43, no. 1, pp. 112-125, 2018.

[88] M. L. Dahms, C. M. Spliid, and J. F. D. Nielsen, "Teacher in a problem-based learning environment-jack of all trades?" European Journal of Engineering Education, vol. 42, no. 6, pp. 1196-1219, 2017.

[89] T. A. Farrell, M. A. Albanese, and P. R. Pomrehn, "Problembased learning in ophthalmology," Archives of Ophthalmology, vol. 117, no. 9, pp. 1223-1226, 1999.

[90] S. Blume, N. Madanchi, S. Böhme, G. Posselt, S. Thiede, and C. Herrmann, "Die lernfabrik-research-based learning for sustainable production engineering," Procedia CIRP, vol. 32, pp. 126-131, 2015.

[91] J. P. Vitta, "The case for a task-teach-task (TTT) approach in the Japanese university EFL speaking context," Journal of Advances in English Language Teaching, vol. 4, no. 6, pp. 78-81, 2016.

[92] M. Espey, "Enhancing critical thinking using team-based learning," Higher Education Research \& Development, vol. 37, no. 1, pp. 15-29, Jan. 2018.
[93] R. Harde, "Team-based learning in the humanities classroom: "women's environmental writing" as a case study," Canadian Journal of Scholarship, Teaching and Learning, vol. 6, no. 3, p. 11, 2015.

[94] D. P. Hunt, P. Haidet, J. H. Coverdale, and B. Richards, "The effect of using team learning in an evidence-based medicine course for medical students," Teaching and Learning in Medicine, vol. 15, no. 2, pp. 131-139, 2003.

[95] J. J. Asher, "The learning strategy of the total physical response: a review," The Modern Language Journal, vol. 50, no. 2, pp. 79-84, 1966.

[96] J. J. Asher, "The total physical response technique of learning," The Journal of Special Education, vol. 3, no. 3, pp. 253-262, 1969.

[97] J. J. Asher and B. S. Price, "The learning strategy of the total physical response: some age differences," Child Development, vol. 38 , no. 4 , p. $1219,1967$.

[98] T. Abraham, "The interactive, virtual management information systems (MIS) classroom: creating an active learning environment on the internet," 1998.

[99] G. Arastoopour, D. W. Shaffer, Z. Swiecki, A. R. Ruis, and N. C. Chesler, "Teaching and assessing engineering design thinking with virtual internships and epistemic network analysis," International Journal of English Education, vol. 32, no. 3, pp. 1492-1501, 2016.

[100] L. K. Zimmermann, "Using a virtual simulation program to teach child development," College Teaching, vol. 61, no. 4, pp. 138-142, 2013.

[101] D. L. Reilly and J. Ring, "Visual thinking strategies: a new role for art in medical education," Family Medicine, vol. 37, no. 4, pp. 250-252, 2005. 